\title{
Vulnerability of the elderly: a conceptual analysis
}

\author{
Vulnerabilidade da pessoa idosa: análise conceitual \\ Vulnerabilidad del anciano: análisis conceptual
}

\section{Keylla Talitha Fernandes Barbosa ' \\ ORCID: 0000-0001-6399-002X}

Fabiana Maria Rodrigues Lopes de Oliveira' ORCID: 0000-0002-2985-7572

\section{Maria das Graças Melo Fernandes'} ORCID: 0000-0001-6294-9930

'Universidade Federal da Paraíba. João Pessoa, Paraíba, Brazil.

How to cite this article:

Barbosa KTF, Oliveira FMRL, Fernandes MGM. Vulnerability of the elderly: a conceptual analysis. Rev Bras Enferm. 2019;72(Suppl 2):337-44. doi: http://dx.doi.org/10.1590/0034-7167-2018-0728

\section{Corresponding Author:}

Keylla Talitha Fernandes Barbosa

E-mail: keyllafernandes@gmail.com

Submission: 09-17-2018 Approval: 01-05-2019

\section{ABSTRACT}

Objective: To analyze the concept of vulnerability of the elderly. Method: A concept analysis, according to the method proposed by Walker and Avant, operationalized through integrative review through search in scientific data portals using the Descriptors: Health vulnerability, aged, health services for the aged, health of the elderly, vulnerable populations and geriatric health services. To compose the literary corpus, 36 studies were selected. Results: Concept antecedents, as well as its attributes, were identified in individual, social and programmatic characteristics, which make up the characteristics of "vulnerability of the elderly", besides consequences of the phenomenon. These characteristics were analyzed with emphasis on aspects that contribute to the process of vulnerability of the elderly. Conclusion: The study demonstrated the multidimensionality of the phenomena studied, highlighting the peculiarities of vulnerability during aging. However, there is a need for further studies on the construct.

Descriptors: Nursing; Aged; Health Vulnerability; Social Vulnerability; Concept Formation.

\section{RESUMO}

Objetivo: Analisar o conceito de vulnerabilidade da pessoa idosa. Método: Trata-se de uma análise de conceito, segundo o método proposto por Walker e Avant, operacionalizada mediante revisão integrativa por meio de busca em portais de dados científicos mediante os Descritores: Health vulnerability, aged, health services for the aged, health of the elderly, vulnerable populations e geriatric health services. Para compor o corpus literário, foram selecionados 36 estudos. Resultados: Identificaram-se os antecedentes do conceito, bem como seus atributos, classificados em características individuais, sociais e programáticas, os quais compõem as características da "vulnerabilidade da pessoa idosa", além das consequências do fenômeno. Procedeu-se a análise das referidas características com ênfase nos aspectos que contribuem no processo de vulnerabilidade da pessoa idosa. Conclusão: $\mathrm{O}$ estudo demonstrou a multidimensionalidade do fenômeno estudado, destacando as peculiaridades próprias da vulnerabilidade durante o envelhecimento. Contudo, é oportuno destacar há a necessidades de estudos mais aprofundados sobre o constructo. Descritores: Enfermagem; Idoso; Vulnerabilidade em Saúde; Vulnerabilidade Social; Formação de Conceito.

\section{RESUMEN}

Objetivo: Analizar el concepto de vulnerabilidad de la persona mayor. Método: Se trata de un análisis de concepto, según el método propuesto por Walker y Avant, operacionalizada mediante revisión integrativa por medio de búsqueda en portales de datos científicos mediante los Descriptores: vulnerabilidad en salud, anciano, servicios de salud para ancianos, salud del anciano. Para componer el corpus literário, se seleccionaron 36 estudios. Resultados: Se identificaron los antecedentes del concepto así como sus atributos, clasificados en características individuales, sociales y programáticas, los cuales componen las características de la "vulnerabilidad de la persona mayor", además de las consecuencias del fenómeno. Se procedió al análisis de dichas características con énfasis en los aspectos que contribuyen al proceso de vulnerabilidad de la persona de edad. Conclusión: El estudio demostró la multidimensionalidad del fenómeno estudiado, destacando las peculiaridades propias de la vulnerabilidad durante el envejecimiento. Sin embargo, es oportuno destacar las necesidades de estudios más profundos sobre el constructo.

Descriptores: Enfermería; Anciano; Vulnerabilidad em Salud; Vulnerabilidad Social; Formación de Concepto. 


\section{INTRODUCTION}

The elderly population's growth is considered one of the most relevant demographic transitions, which happens fast and abruptly, especially in the developing countries, without adequate monitoring of social and economic progress. A reflection of these transformations can be observed through international statistical projections, which show that between 2000 and 2050, the proportion of inhabitants of the planet over 60 will double from $11 \%$ to $22 \%$. In absolute numbers, this group will increase from 605 million to 2000 million over half a century ${ }^{(1)}$.

The increase in the proportion of elderly people in the Brazilian population raises discussion about the need for theoretical tools and models that direct the practice regarding the elderly's health and understand their breadth and complexity. Therefore, in the context of Gerontology the concept of vulnerability is explored, which can be defined as the individual who will not necessarily suffer damage, but is more susceptible since it has significant disadvantages, especially regarding quality of life. It should be emphasized that the state of vulnerability is associated with individual and, above all, collective situations and contexts ${ }^{(2)}$.

Aging implies an increased risk for the development of vulnerability, since senescence is a process permeated by increasing changes, which involve a set of individual and collective aspects that exert influence on the conditions of life and health of the individual. In order to adequately address vulnerability, nurses need to be able to critically analyze such a concept and identify vulnerable older people at different levels of health care. They should also consider that aging is a multidimensional and multidetermined event, where individual, collective and contextual aspects can favor illness and difficulties in accessing the protection resources available in society ${ }^{(3)}$.

The degree of vulnerability is subject to a series of combinations of elements present in physical, social and programmatic domains, as well as experiences relative to each of them in the past, and deal with the facilities and difficulties of life ${ }^{(4)}$. The construct mentioned above helps to reflect on how the presence or absence of physical, psychological or social problems can influence quality of life and perception of health.

Bearing in mind the complexity and multidimensionality of vulnerability, there is a need to elucidate carefully the meaning of this concept in the elderly population and thus to describe and explain the phenomena that involve vulnerability and aging. It should be emphasized that for the construction of nursing knowledge, it is necessary to analyze and structure concepts of interest for its development, as well as its theoretical-philosophical foundation, defining its attributes, definitions, antecedents and consequences ${ }^{(5)}$.

It is also emphasized that, the conceptual analysis consists of an intellectual exercise that seeks to solve problems of words and expressions used, which seeks to clarify a concept of interest and, thus, to contribute to an adequate applicability in the care provided. Due to the continuous and complex modifications of scientific knowledge over time, the need to analyze concepts of interest for everyday practice emerges. Through such an analysis, it is possible to experience exchange between knowledge, explain the nature of nursing, define its specific field and its scientific methodology ${ }^{(6)}$.
The development of this study will provide evidence that can broaden the understanding about vulnerability of the elderly, seeking to clarify the several specific characteristics, which include the attributes, antecedents and consequences of the concept in question. Therefore, the construction of knowledge favors theoretical basis to the clinical practice of nurses, as well as elucidate studies within the scope of academic practice.

\section{OBJECTIVE}

To analyze the concept of vulnerability of the elderly.

\section{METHOD}

\section{Ethical aspects}

For the performance of this study, only the available literature was used in online databases. Therefore, it was not necessary ethical consideration for being scientific articles in the public domain, not involving human beings and, therefore, was not submitted to the consideration of the Ethics and Research Committee.

\section{Theoretical-methodological framework and type of study}

This is a descriptive study with a qualitative approach using a conceptual analysis model proposed by Walker and Avant ${ }^{(7)}$. The method, elucidated for the first time in 1983, consists of eight stages, proposes an interactive process with the purpose of analyzing the structure and function of the basic elements of a concept. This method distinguishes it with the aim of refining ambiguities and clarifying vague concepts, thus contributing to the development of nursing practice. Thus, it is possible to clarify meanings and define terms in order for authors and readers to share a common language.

The authors listed a sequential approach, which consists of the following steps: concept selection; determination of the conceptual analysis objectives; identification of possible uses of the concept; delimitation of essential attributes; observation of the model case; recognition of boundary, related, counter, invented and illegitimate cases; identification of antecedents and consequences and, finally, the definition of empirical references ${ }^{(7)}$. It is noteworthy that, for the construction of the present study, equivalent steps similar to those developed during the process of integrative review of the literature.

\section{Methodological procedures}

\section{Data source}

In order to identify the characteristics related to the concept, an integrative review of the literature was carried out. To do so, it was established the search in sources indexed in scientific data portals, through the identification of articles, theses and dissertations published in the following electronic databases: Banco de Teses e Dissertações (Theses and Dissertations Database) of the Coordination for Improvement of Higher Level Personnel (BTD), Cumulative Index to Nursing and Allied Health Literature (CINAHL), Latin American \& Caribbean Health Sciences Literature (LILACS), Medical Literature Analysis and Retrieval Sistem online (MEDLINE), SciVerse Scopus and Web of Science. 


\section{Collection and organization of data}

In order to ensure a careful search of the literature, the following terms were delimited according to the vocabulary of the Health Sciences Descriptors (DeCS): health vulnerability/vulnerabilidad en salud, aged/anciano, health services for the aged/servicios de salud para ancianos, and health of the elderly/salud del anciano.

Also used as a reference is the terminology available in the Medical Subject Heading (MeSH), which comprises a set of terms called descriptors and organized into a hierarchical structure that allows searching at various levels of specificity. After analyzing the aforementioned database, the following terms were added: aged, vulnerable populations and geriatric health services. It should be noted that the descriptors were combined in their various possibilities in the fields "title", "abstract" and "subject", always considering vulnerability in health as a key descriptor. In addition, to perform this search, the descriptors were used in isolation and with the Boolean marker AND with the objective to refine the findings.

In order to compose the literary corpus, the following inclusion criteria were established: manuscripts published in Portuguese, English or Spanish; availability of the text in its entirety; and that it contemplated elements referring to the concept of vulnerability of the elderly, without time delimitation of period of publication.

Regarding the exclusion criteria, the following conditions were established: editorials, letters to the editor, annals of events and pilot tests, as well as research addressing vulnerability related to specific problems such as mental health, HIV/AIDS, natural disasters, hunger and environmental stressors, such as heat waves.

The search for publications comprised between January and March 2017, totaling 750 articles and 36 theses and dissertations. Due to the significant number of studies, it was decided to delimit the sample through the application of two refinement tests. Initially, 786 studies were pre-selected, which were subjected to careful reading and analysis of the pre-textual elements, in order to verify if there were the essential criteria that addressed the concept investigated. Therefore, it was possible to exclude 713 surveys, since they are not available in their entirety, do not respond to the guiding question or by duplication in the consulted databases.

\section{Data analysis}

In the second refinement, after exhaustive and comprehensive reading of the studies, considering the pertinence and consistency of their content, those who did not approached the object of the present research were excluded. After these refines of the literature, the sample consisted of 36 articles, theses or dissertations.

For the development of this synthesis, fragments or units of analysis useful to clarify the concept studied are highlighted. Therefore, to facilitate the categorization of the selected evidence, a structured tool was used, containing information on the characterization of the studies (type of study, year of publication, area of performance of authors and language) and the following guiding question: what are the characteristics, the conditions that make it feasible and the consequences of the vulnerability of the elderly? At this stage, the attributes, antecedents and consequents of the concept studied were identified, as presented in Figure 1 and discussed based on the literature.

\section{RESULTS}

It was verified that most of the selected scientific works were developed in the South American continent (12; 34.3\%), especially in Brazil, where 11 studies were published on the researched topic. Research on vulnerability among the elderly was started in 2000, with a predominance of publications in the year 2015 (07; 20.0\%), followed by $2014(05 ; 14.0 \%)$ and 2010 (05; 14.0\%), evidencing the increased interest of researchers in improving knowledge in this area in recent years.

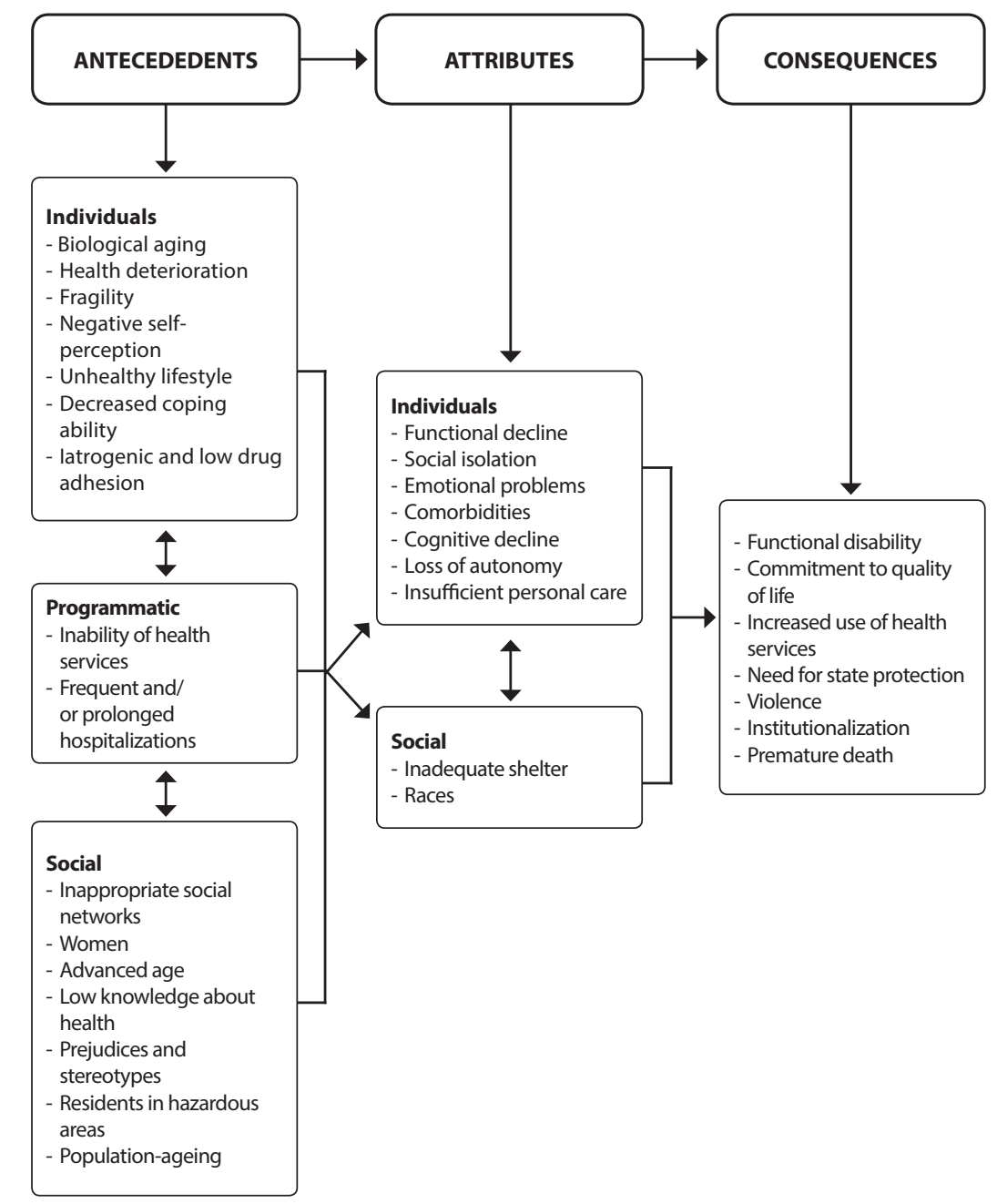

Figure 1 - Antecedents, attributes and consequences of the concept of vulnerability of the elderly, identified from an integrative literature review, $2018(\mathrm{~N}=36)$ 
As to the area of knowledge, studies developed in medicine $(13 ; 37.2 \%)$ and nursing $(09 ; 25.9 \%)$ predominated. However, it was evidenced an approach of the subject in different disciplines, such as Sociology, Theology and Architecture. This data ratifies the importance of elucidating and refining the concept, constructing a clear and precise meaning of the phenomenon within a given science, such as nursing.

Regarding the language, there was a predominance of researches published in English (22;62.9\%), since much of the material analyzed came from scientific articles published internationally. Regarding the type of study, it was verified that the majority was classified as cross-sectional with a quantitative approach $(14 ; 40 \%)$, followed by cross-sectional with a qualitative approach $(07 ; 20 \%)$ and longitudinal studies $(07 ; 20 \%)$. Regarding the essential elements of the phenomenon, antecedents, attributes and consequences, these are presented in categories and subcategories of analysis, as shown in Figure 1.

\section{DISCUSSION}

\section{Antecedents of the concept of vulnerability of the elderly}

Antecedents of the concept are determining factors that occur prior to the event. Through the analysis of the literature, it is verified that vulnerability of the elderly results from different conditions, which are correlated with each other, standing out biological, social and programmatic factors. Elements such as biological aging, deterioration of health, inability of health services, frequent hospitalizations, inadequate social networks and female sex were identified as precursors of the concept studied.

From the biological point of view, aging is a natural process that, over the years, imposes several changes and produces structural and behavioral effects that influence the physical and social aspects, directly affecting the biopsychosocial context and quality of life of people who grow old ${ }^{(8)}$.

Aging is a natural and physiological process, heterogeneous and with its own peculiarities, since it is related to the material and symbolic forms that socially identify each individual, varying with the time, place and culture that permeate them, appearing in each human being singularly ${ }^{(9)}$.

Although senescence can be understood as a non-pathological process, there is an inevitable progressive decrease of the functional reserve. Under conditions of overload and in the presence of cardiovascular complications and emotional stress, it can favor the installation of chronic pathological conditions, characterizing, in this way, senility, which may favor vulnerability ${ }^{(10)}$.

Studies suggest that older people experience a sense of vulnerability due to declining physical and/or mental health ${ }^{(11)}$. Factors such as deterioration of health, decreased sense, cognitive deficits, psychological decline, recurrent episodes of falls and frailty, have been strongly related to the vulnerability of the elderly ${ }^{(12)}$. Such conditions favor a strong search for health services. However, complaints for obtaining medical consultations increased in the same direction. Studies show that there is still a significant proportion of elderly people who do not regularly follow up on medical care due to the inefficiency of the health centers close to their home and away from the major reference centers ${ }^{(11-12)}$.
The socioeconomic profile influences the search for such services. Older and less educated elderly showed a lower search for health services. In addition, prolonged treatments, side effects of drugs and the lack of knowledge about the evolution of the disease interfere in the motivation of the people in search of qualified care ${ }^{(10,13)}$.

It should be emphasized that health services are still based on curative practices, with a low emphasis on chronic conditions and the specific needs arising from aging. There is a violation of rights of the elderly through the State' omission in the provision and evaluation of institutions that provide care, as well as the lack of training of health professionals to guide the elderly and their caregiver. Therefore, it is necessary to periodically evaluate the completeness and equity of the actions, as well as access to services, their quality and the existence of multidisciplinary teams, denning programmatic vulnerability in the population cared for ${ }^{(14-16)}$.

One of the consequences of the poor quality of preventive services is the recurrent hospitalization of the elderly. It is considered a significant stressor and is associated with progressive functional decline, which renders the elderly vulnerable to adverse health outcomes such as institutionalization and early mortality. A research shows that hospitalization can be an important factor that precedes vulnerability, particularly in those who experienced an average of two hospitalizations in the last 12 months preceding the study ${ }^{(17)}$.

In this context, there are different dimensions of vulnerability involved in hospitalization. The elderly find themselves distanced from their objects and routines, smells of their environment, memories and all the elements that help them stay alert and active. Therefore, the family separation environment can lead to isolation, loss of temporal references that creates a strong psychological impact and mental disorders ${ }^{(18)}$.

It is worth pointing out that vulnerability consists of a multidimensional construct, where behavioral, sociocultural, economic and political conditions interact with biological processes throughout life. In this way, inadequate social networks stand out as an important antecedent. Older people report family ties as central elements of their lives because family members often show affection for each other and help each other by providing innumerable forms of instrumental and emotional support ${ }^{(19)}$.

Research has shown that family availability can be considered a protective factor for aging, since vulnerability, loneliness, depression and poor health were strongly related to the availability of kinship. One of the most common causes of the dissolution of family support is divorce, which has a strong impact on the elderly's mental well-being due to the reduced availability of trust relationships and reduction of economic security ${ }^{(20)}$.

Another important precedent evidenced in the literature was gender, since the highest morbidity rates are verified among women. In addition, there is also the need for health care and the greater likelihood of living in poverty compared to men ${ }^{(21-}$ ${ }^{23)}$. A Canadian study of elderly people living in the community showed that life expectancy among women was negatively affected by social issues such as isolation, economic adversity and loneliness, which culminated in lower resources and less social support ${ }^{(24)}$. 


\section{Attributes of the concept of vulnerability of the elderly}

Through the identification of attributes, it is possible to describe the characteristics of a particular concept. These attributes act as elements for differential diagnoses, that is, to discriminate what is an expression of the concept of what is not ${ }^{(25-26)}$.

The determination of the essential attributes of vulnerability of the elderly was guided by the following questions: what words, expressions or characteristics were used by the authors to describe this phenomenon? What ideas are the researchers investigating about the concept? From these questions was it possible to list functional decline, social isolation, inadequate housing and races as the main attributes of the concept?

As the population ages, there is a need to better understand this process. With advancing age, individuals may present with different types of illnesses, leading to disease accumulation, increased vulnerability, recurrent episodes of falls, prolonged hospitalization, and the development of disabilities ${ }^{(27)}$. In this context, functional ability is highlighted, which is dimensioned in terms of ability, independence and capacity to perform certain daily tasks related to personal care and protection. Functional performance in basic and instrumental activities of daily living has been a widely accepted and recognized parameter for the evaluation of functional ability ${ }^{(28)}$.

Studies developed in Brazil have identified the routine activities that the elderly reported to have the greatest difficulty in performing, such as: shopping without assistance from third parties, performing light domestic tasks, taking responsibility for personal finances and bathing alone ${ }^{(23,29)}$. It should be noted that the elderly who have experienced a decline in functional status are vulnerable to adverse health outcomes, such as increased risk of hospitalization, institutionalization and early mortality. Those classified as vulnerable were 4.2 times more likely to have functional decline or die within two years of the initial evaluation ${ }^{(30-32)}$.

It is opportune to recognize multicausality in the decline of functional ability. In addition to biological influences, such as heart disease, diabetes, arterial hypertension and Parkinson's disease, social determinants stand out as predisposing to this phenomenon ${ }^{(33)}$. Research shows that lower social engagement, lack of support networks and low socioeconomic level predict functional and cognitive decline, as well as greater occurrence of chronic and infectious diseases ${ }^{(34-36)}$. The continued ability to remain independent and participate in society is a primary concern for the elderly population. As people age and become more vulnerable, their social circumstances particularly affect their health, necessitating greater affective support through frequent social and family contacts ${ }^{(37)}$. There is also the possibility of social losses, physical and mental abilities, characterized by diminished interest and empathy for the world or for other people.

The maintenance of functional ability is related to the possibility of the elderly integrating socially, through social relations with family and friends, as well as participation in cultural and civic activities. A longitudinal study pointed out that different factors may contribute to social isolation, such as old age, living alone, physical health impairments, cognitive decline and limited mobility, as well as those who do not have access to a private car or are totally dependent on public transportation ${ }^{(38)}$.
The modern family situation favors isolation, since culturally family members are not very receptive to accommodating and accompanying older members, which can create a layer of vulnerability for many older people, in which they feel alone, isolated, and a burden on the relatives ${ }^{(18)}$. In order to resolve this situation, it is opportune to stimulate sociopsychological elements, such as participation in physical and social leisure activities, strong interpersonal bonding and participation in groups. Independence and satisfaction with life demonstrated a strong influence in the prevention of dementias, and greater survival(39).

Besides individual factors, it is opportune to emphasize the importance of social vulnerability in the aging process. Scientific evidence has shown that living in a poor and deprived neighborhood is associated with poor cardiovascular health, higher mortality rates, increased incidence of infectious diseases, prevalence of depression and less healthy behavior, as well as the prevalence of functional limitation and poorer health self-assessment ${ }^{(13,24,40)}$.

Aggregate measures, such as the average income of the neighborhood, lack of healthy lifestyle promotion campaigns, low schooling levels and high unemployment rates are useful in describing social contexts in which people live and allowing the study of so-called contextual effects on health ${ }^{(41)}$. In addition, residing in neighborhoods with low socioeconomic status, high minority grouping and high population density culminates in reduced access to health facilities and services, which discourages people from joining regular physical exercises, directly influencing their health status ${ }^{(40)}$.

Although not mentioned in the selected studies, race is an important attribute of vulnerability among the elderly. Compared to white, black and mulatto people have lower schooling and income, higher unemployment and precarious working relationships, worse housing conditions and greater difficulty in accessing goods and services ${ }^{(29)}$.

Such differences influence mortality rates, since white elderly women report better health conditions and have a life expectancy of 6.4 years longer than black women ${ }^{(42)}$. The over-mortality of black people is mainly due to inequities in access to quality health, thus revealing the social and programmatic vulnerability to which this population is exposed ${ }^{(43)}$.

\section{Consequences associated with the concept of vulnerability of the elderly}

The identification of consequences relates to situations, events or events that occur after the determination of the concept. From the careful reading, it was verified functional disability and impairment of quality of life as the main consequences of vulnerability of the elderly.

The lack of ability to perform daily tasks, which are indispensable to a community life, defines functional disability. Some factors, such as poor self-assessed health, heart disease, diabetes, hypertension, Parkinson's disease, mental disorders and depression, are strongly associated with marked and progressive decline in functional ability ${ }^{(29,44)}$.

Studies have shown that elderly people living in socially vulnerable neighborhoods had a significant functional impairment due to low wages, low schooling, lower participation in 
the community and dissatisfaction with social life ${ }^{(40)}$. Although functional disability is strongly related to age, not all elderly people have such a disability and not all are permanent and immutable. Researchers state that some elderly people can improve their functional ability over the years by preventing morbidities and maintaining physical and social activities ${ }^{(19)}$.

It is also worth noting that the incidence of vulnerability may favor the decline of quality of life, which is largely determined by the individual's ability to maintain autonomy and independence $^{(1,8)}$. Many factors favor the preservation of quality of life, among them: the maintenance of physical health, the ability to perform activities of daily living, adequate psychological conditions, satisfaction with life, preservation of autonomy, social support and shelter in a nice and safe place ${ }^{(19)}$.

The elderly expect to be recognized as citizens and maintain their autonomy. However, low incomes associated with health problems challenge independence, culminating in a deleterious effect on quality of life, particularly for those who attach great importance to individualism and self-determination ${ }^{(19)}$. It is also emphasized that social issues, such as the low value of pensions, which cannot provide adequate social conditions, being alone, age discrimination, low schooling and little involvement with the community, may predispose the vulnerability ${ }^{(23)}$.

All these adverse conditions can diminish quality of life and autonomy of the elderly. Therefore, a better understanding of the aging process and the early identification of factors that characterize individuals as vulnerable is fundamental to directing preventive interventions. Efforts to prevent, resolve or postpone morbidity and its consequences therefore promote not only quality of life but also the reduction of vulnerability and the increase in life expectancy ${ }^{(8,44)}$.

\section{Study limitations}

As a limitation, the small number of publications on the phenomenon studied is highlighted. Although the term "vulnerability" is widely used in several disciplines, especially in Collective Health, scientific production in the field of Elderly Health is still incipient, especially at the national level. Therefore, it is recommended to carry out new studies on the subject in order to clarify and spread knowledge about vulnerability of the elderly.

\section{Contributions to the field of nursing}

Regarding the contributions to nursing, it is known that the conceptual analysis makes possible the identification of the essential characteristics of the phenomenon. It also identifies the antecedents, attributes and consequences, thus allowing standardization of the use and improvement of essential concepts for the professional and scientific improvement of nursing.

In addition, concept refinement can contribute to elucidation of the phenomenon, influencing the development of actions directed to resolve or combat vulnerability in the elderly, grounding the knowledge of nursing practice in relation to the presented problem.

\section{FINAL CONSIDERATIONS}

Concept analysis of vulnerability of the elderly allowed an approximation with the theme from the survey of the essential characteristics, attributes and consequences of the problem studied. Although it is commonly used, the concept has been broad, complex and subjective, since there is no agreement in the literature about this phenomenon, thus showing different generic and incipient definitions that do not consider the specificities of the elderly.

Vulnerability is seen as a multidimensional construct where behavioral, sociocultural, economic, and political conditions interact with biological processes throughout life. Therefore, it is important to highlight the need for more in-depth studies on understanding the concept, allowing its clarification, in order to provide subsidies for its practical applicability to the needs of the elderly.

The findings evidenced through critical analysis of the literature offered relevant theoretical materials, highlighting the peculiarities of the vulnerability during aging, with specific characteristics that differ from other phases of life. However, despite the importance of the phenomenon, this is little explored in Gerontology, in which there is an understanding of the different nuances that make up the vulnerability.

Therefore, it is necessary researches that can favor the development of such concept, in order to explore how this manifests itself in the quotidian of the elderly. The theoretical and practical elucidation of the characteristics of vulnerability allows health professionals the scientific basis necessary for the elaboration of effective strategies in the care for the elderly population.

\section{FUNDING}

This work was carried out during the Doctorate course in nursing, with financial support from the Coordination for Improvement of Higher Education Personnel (CAPES - Coordenação de Aperfeiçoamento de Pessoal de Nível Superior).

\section{REFERENCES}

1. Organização Mundial da Saúde. Relatório Mundial de Envelhecimento e Saúde. Genebra (Suíça): 2015.

2. Carmo ME, Guizardi FL. The concept of vulnerability and its meanings for public policies in Health and social welfare. Cad Saúde Pública [Internet]. 2018 [cited 2018 Aug 03];34(3):1-14. Available from: http://www.scielo.br/pdf/csp/v34n3/1678-4464-csp-34-03-e00101417.pdf

3. Barbosa KTF, Costa KNFM, Pontes MLF, Batista PSS, Oliveira FMRL, Fernandes MGM. Aging and individual vulnerability: a panorama of older adults attended by the Family Health strategy. Texto Contexto Enferm [Internet]. 2017 [cited 2018 Aug 10];26(2):1-10. Available from: http:// www.scielo.br/pdf/tce/v26n2/0104-0707-tce-26-02-e2700015.pdf 
4. Ayres JRCM, Calazans GJ, Saletti HCJ, França IJ. Risco, vulnerabilidade e práticas de prevenção e promoção da saúde. In: Akerman M, Campos GWS, Carvalho YM, Drumond MJ, Minayo MCSH, editors. Tratado de Saúde Coletiva. 2 ed. Rio de Janeiro: Editora Fiocruz; 2012. 375-418.

5. Talmelli LFS, Gratão ACM, Rodrigues RAP. Modelo híbrido para desenvolvimento de conceito em Enfermagem utilizando revisão integrativa e análise de conteúdo. Saude Transf Soc [Internet]. 2016 [cited 2018 Aug 10];7(1):9-15. Available from:http://incubadora.periodicos.ufsc.br/ index.php/saudeetransformacao/article/view/4118/4531

6. Mangueira SO, Lopes MVO. Família disfuncional no contexto do alcoolismo: análise de conceito. Rev Bras Enferm [Internet]. 2014 [cited 2018 Aug 14];67(1):149-54. Available from: http://www.scielo.br/pdf/reben/v67n1/0034-7167-reben-67-01-0149.pdf

7. Walker LO. Avant KC. Strategy for theory construction in nursing. 4ed. Norwalk, CT: Appleton \& Lange; 2005.

8. Agu FC. Healthy aging reports: a conceptual and ethical analysis of vulnerability and independency. Sage [Internet]. 2013 [cited 2018 Aug 14];1-7. Available from: http://journals.sagepub.com/doi/full/10.1177/2158244013491413

9. Fernandes MGM, Garcia, LG. O sentido da velhice para homens e mulheres idosos. Saúde Soc [Internet]. 2010 [cited 2018 Aug 14];19(4):77183. Available from: http://www.scielo.br/pdf/sausoc/v19n4/05.pdf

10. Berardinelli LMM, Santos I, Santos MLCS, Lima TCL, Missio AC. Identificando vulnerabilidade para complicações cardiovasculares em idosos: uma estratégia para o cuidado. Rev Enferm UERJ [Internet]. 2011 [cited 2018 Aug 14];19(4):541-6. Available from: http://www.facenf.uerj.br/ v19n4/v19n4a06.pdf

11. Brocklehurst $\mathrm{H}$, Laurenson M. A concept analysis examining the vulnerability of older people. British J Nurs[Internet]. 2008 [cited 2018 Aug 14];17(21):1354-7. Available from: https://www.ncbi.nlm.nih.gov/pubmed/19060820

12. Sarvimäki A, Stenbock-Hult B. The meaning of vulnerability to older persons. Nurs Ethics [Internet]. 2016 [cited 2018 Aug 14];23(4):372-83. Available from: https://www.ncbi.nlm.nih.gov/pubmed/25552588

13. Braga LS, Macinko J, Proietti FA, César CC, Lima-Costa MF. Intra-urban differences in vulnerability among the elderly population. Cad Saúde Pública [Internet]. 2010 [cited 2018 Aug 14];26(12):2307-15. Available from: http://www.scielo.br/pdf/csp/v26n12/09.pdf

14. Ayres JRCM, Paiva V, França Jr I, Gravato N, Lacerda R, Negra DL et al. Vulnerability, human Rights, and comprehensive health care needs of young people living with HIV/AIDS. Am J Public Health [Internet]. 2006 [cited 2018 Aug 14];96(6):1001-6. Available from: https://www.ncbi. nlm.nih.gov/pubmed/16449593

15. Sthal HC, Berti HW, Palhares VC. Caracterização de idosos internados em enfermaria de pronto-socorro quanto à vulnerabilidade social e programática. Esc Anna Nery [Internet]. 2010 [cited 2018 Aug 14];14(4):697-704. Available from: http://dx.doi.org/10.1590/ S1414-81452010000400007

16. Silveira J, Scherer F, Deitos A, Dal Bosco SM. Fatores associados à hipertensão arterial sistêmica e ao estado nutricional de hipertensos inscritos no programa Hiperdia. Cad. saúde colet. [Internet]. 2013 [cited 2018 Aug 14];21(2):129-34. Available from: http://dx.doi. org/10.1590/S1414-462X2013000200005

17. Bell SP, Schnelle J, Nwosu SK, Schildcrout J, Goggins K, Cawthons C, et al. Development of a multivariable model to predict vulnerability in older American patients hospitalised with cardiovascular disease. BMJ Open [Internet]. 2015 [cited 2018 Aug 14];5:1-8. Available from: https://bmjopen.bmj.com/content/5/8/e008122

18. Luna F. Vulnerability, an interesting concept for public Health: the case of older persons. Public Health Ethics [Internet]. 2014 [cited 2018 Aug 14];1-15. Available from: https://academic.oup.com/phe/article-abstract/7/2/180/2909432

19. Grundy E. Ageing and vulnerable elderly people: European perspectives. Ageing Soc [Internet]. 2006 [cited 2018 Aug 14];26:105-34. Available from: https://www.cambridge.org/core/journals/ageing-and-society/article/ageing-and-vulnerable-elderly-people-european-per spectives/38FE71F6EC2FA12FBAFD30825B011E12

20. Moor JA, Graaf PM, Komter A. Family, welfare state generosity and the vulnerability of older adults: a cross-national study. J Aging Stud [Internet]. 2013 [cited 2018 Aug 14];27(4):347-67. Available from: https://www.ncbi.nlm.nih.gov/pubmed/24300055

21. McGee HM, O'Hanlon A, Barker M, Hickey A, Montgomery A, Conroy R, et al. Vulnerable older people in the Community: relationship between the vulnerable elders survey and Health servisse use. J Am Geriatr Soc [Internet]. 2008 [cited 2018 Aug 14];56:8-15. Available from: https://www.ncbi.nlm.nih.gov/pubmed/18184202

22. Bell SP, Schnelle J, Nwosu SK, Schildcrout J, Goggins K, Cawthon C, et al. Development of a multivariable model to predict vulnerability in older American patients hospitalised with cardiovascular disease. BMJ Open [Internet]. 2015 [cited 2018 Aug 14];5(8). Available from: https://bmjopen.bmj.com/content/5/8/e008122

23. Barbosa KTF, Fernandes MGM, Oliveira FMRL, Tibúrcio ABCB, Alves, ABR, Ramos CEB. Vulnerabilidade física entre idosos: diferencias por sexo Cultura Cuid [Internet]. 2015 [cited 2018 Aug 14];19(42):1-11. Available from: http://dx.doi.org/10.14198/cuid.2015.42.09

24. Armstrong JJ, Andrew MK, Mitnitski A, Launer LJ, White LR. Social vulnerability and survival across levels of frailty in the Honolulu-Asia Aging Study. Age Ageing [Internet]. 2015 [cited 2018 Aug 14];44:709-12. Available from: https://www.ncbi.nlm.nih.gov/pubmed/25758407

25. Rodgers BL. Concept analysis: an evolutionary view. In Rodgers BL, Knafl KA. Concept development in nursing: foundations, techniques and applications. Philadelphia: Saunders, 2000, p. 77-102.

26. Fernandes MGM, Nóbrega MML, Garcia TR, Macêdo-Costa KNF. Análise conceitual: considerações metodológicas. Rev Bras Enferm [Internet]. 2011 [cited 2018 Aug 14];64(6):1150-6. Available from: http://dx.doi.org/10.1590/S0034-71672011000600024 
27. Fried LP, Ferrucci L, Darer J, Williamson JD, Anderson G. Untangling the concepts of disability, frailty, and comorbidity: implications for improved targeting and care. J Gerontol A Biol Sci Med Sci [Internet]. 2004 [cited 2018 Aug 14];59(3):255-63. Available from: https://www. ncbi.nlm.nih.gov/pubmed/15031310

28. Ursine PGS, Cordeiro HA, Moraes CL. Prevalência de idosos restritos ao domicílio em região metropolitana de Belo Horizonte (Minas Gerais, Brasil). Ciênc Saúde Coletiva [Internet]. 2011 [cited 2018 Aug 14];16(6):2953-62. Available from: http://dx.doi.org/10.1590/ S1413-81232011000600033

29. Maia FOM., Duarte YAO, Secoli, SR, Santos JLF, Lebrão ML. Cross-Cultural Adaptation of the Vulnerable Elders Survey-13(VES-13): helping in the identification of vulnerable older people. Rev Esc Enferm USP [Internet]. 2012 [cited 2018 Aug 15];46(spe):116-22. Available from:http:// www.scielo.br/pdf/reeusp/v46nspe/en_17.pdf

30. Pulignano G, Del Sindaco D, Di Lenarda A, Tarantini L, Cioffi G, Gregori D, et al. Usefulness of frailty profile for targeting older heart failure patients in disease management programs: a cost-effectiveness, pilot study. J Cardiovasc Med [Internet]. 2010 [cited 2018 Aug 15];11:73947. Available from: https://www.ncbi.nlm.nih.gov/pubmed/20736784

31. Min L, Yoon W, Mariano J, Wenger NS, Elliot MN, Kamberg C, et al. The vulnerable elders-13 survey predicts 5-year functional decline and mortality outcomes in older ambulatory care patients. J Am Geriatr Soc [Internet]. 2009 [cited 2018 Aug 15];57(11):2070-6. Available from: https://www.ncbi.nlm.nih.gov/pubmed/19793154

32. Go AS, Mozaffarian D, Roger VL, Benjamin EJ, Berry JD, Blaha MJ, et al. Heart disease and stroke statistics 2014 update: a report from the American Heart Association. Circulation [Internet]. 2014 [cited 2018 Aug 15];129(3). Available from: https://www.ncbi.nlm.nih.gov/ pubmed/24352519

33. Rubio AE, Lazaro AA, Martinez TT, Magallón B. Enfermedades crónicas y deterioro funcional para las actividades de la vida diaria em población mayor no institucionalizada. Rev Española Geriatr Gerontol[Internet]. 2009 [cited 2018 Aug 15];44(5):244-50. Available from: http://www.elsevier. es/es-revista-revista-espanola-geriatria-gerontologia-124-articulo-enfermedades-cronicas-deterioro-funcional-las-S0211139X0900119X

34. Wallace LMK, Theou O, Pena F, Rockwood K, Andrew MK. Social vulnerability as a predictor of mortality and disability: cross-country differences in the survey of health, aging, and retirement in Europe (SHARE). Aging Clin Exp Res [Internet]. 2015 [cited 2018 Aug 15];27:36572. Available from: https://www.ncbi.nlm.nih.gov/pubmed/25213145.

35. Jang Y, Poon LW, Kim SY, Kishin B. Self-perception of aging and Health among older adults in Korea. J Aging Stud[Internet]. 2004 [cited 2018 Aug 15];18(4):485-96. Available from: https://www.sciencedirect.com/science/article/abs/pii/S0890406504000404

36. Seidel D, Crilly N, Matthews FE, Jagger C, Brayne C, Clarkson PJ. Patterns of functional loss among older people: a prospective analysis. Hum Factors [Internet]. 2009 [cited 2018 Aug 15];51(5):669-90. Available from: https://www.ncbi.nlm.nih.gov/pubmed/20196292

37. Cahir C, Moriarty F, Teljeur C, Fahey T, Bennett K. Potentially inappropriate prescribing and vulnerability and hospitalization in older Community-dwelling patients. Ann Pharmacother [Internet]. 2014 [cited 2018 Aug 15];48(12):1546-54. Available from: https://www.ncbi. nlm.nih.gov/pubmed/25248541

38. Barnes M, Blom A, Cox K, Lessof C, Walker A. The social exclusion of older people: evidence from the first wave of the English Longitudinal Study of Ageing (ELSA): final Report. Social Research in Transport (SORT) Clearinghouse: London; 2006.

39. Andrew MK, Rockwood K. Social vulnerability predicts cognitive decline in a prospective cohort o folder Canadians. Alzheimer's e dementia [Internet]. 2010 [cited 2018 Aug 15];6:319-25. Available from: https://www.ncbi.nlm.nih.gov/pubmed/20630414

40. An R, Xiang X. Social vulnerability and leisure-time physical inactivity among US adults. Am J Health Behay [Internet]. 2015 [cited 2018 Aug 15];39(6):751-60. Available from: https://www.ncbi.nlm.nih.gov/pubmed/26450542

41. Andrew MK, Keef JM. Social vulnerability from a social ecology perspective: a cohort study of older adults from the National Population Health Survey of Canada. BMC Geriatrics [Internet]. 2014 [cited 2018 Aug 15];14(90):1-14. Available from: https://bmcgeriatr.biomedcentral. com/articles/10.1186/1471-2318-14-90

42. Camarano AA. Mulher idosa: suporte familiar ou agente de mudança? Estud Av [Internet]. 2003 [cited 2018 Aug 15];17(49):35-63. Available from: http://dx.doi.org/10.1590/S0103-40142003000300004

43. Volochko A, Vidal NP. Desigualdades raciais na saúde: mortalidade nas regiões de saúde paulistas, 2005. BIS: Bol Inst Saúde [Internet]. 2010 [cited 2018 Aug 15];12(2):143-53. Available from: http://periodicos.ses.sp.bvs.br/scielo. php?script=sci_arttext\&pid=S1518-18122010000200008\&lng=pt

44. Moser C, Spagnoli, J, Santos-Eggimann, B. Self-perception of aging and vulnerability to adverse outcomes at the age of 65-70 years. J Gerontol B Psychol Sci Soc Sci [Internet]. 2011 [cited 2018 Aug 15];66(6):675-80. Available from: https://www.ncbi.nlm.nih.gov/ pubmed/21775698 